\title{
Paracetamol overdose in Hong Kong: is the 150-treatment line good enough to cover patients with paracetamol-induced liver injury?
}

\author{
Simon TB Chan *, CK Chan, ML Tse
}

This article was published on $31 \mathrm{Jul}$ 2015 at www.hkmj.org.

\section{A B S T R A C T}

Objectives: To evaluate the failure rate of the 150-treatment line for paracetamol overdose in Hong Kong, and the impact if the treatment threshold was lowered.

Design: Case series.

Setting: Public hospitals, Hong Kong.

Patients: All patients with acute paracetamol overdose reported to the Hong Kong Poison Information Centre from 1 January 2011 to 31 December 2013 were studied and analysed for the timed serum paracetamol concentration and their relationship to different treatment lines. Presence of significant liver injury following paracetamol overdose was documented. The potential financial burden of different treatment lines implemented locally was estimated.

Results: Of 893 patients, 187 (20.9\%) had serum paracetamol concentration above the 150-treatment line, $112(12.5 \%)$ had serum paracetamol concentration between the 100- and 150-treatment lines, and 594 (66.5\%) had serum paracetamol level below the 100-treatment line. Of the 25 (2.8\%) patients who developed significant liver injury, two were between the 100- and 150-treatment lines, and the other two were below the 100-treatment line. The failure rate of the 150-treatment line was $0.45 \%$. Lowering the treatment threshold to the 100-treatment line might lower the failure rate of the treatment nomogram to $0.22 \%$ but approximately 37 more patients per year would need to be treated. It would incur an additional annual cost of HK\$189131 (US\$24248), and an additional 1.83 anaphylactoid reactions per year. The number needed-to-treat to potentially reduce one significant liver injury is 112 .

Conclusions: Lowering the treatment threshold of paracetamol overdose may reduce the treatmentline failure rate. Nonetheless such a decision must be balanced against the excess in treatment complications and health care resources.

\section{Hong Kong Med J 2015;21:389-93}

DOI: 10.12809/hkmj144481

\section{${ }^{1}$ STB Chan *, MB, BS}

${ }^{2}$ CK Chan, Dip Clin Tox, FHKAM (Emergency Medicine)

${ }^{2}$ ML Tse, FHKCEM, FHKAM (Emergency Medicine)

\section{Department of Accident and Emergency}

${ }_{2}$ Hong Kong Poison Information Centre

United Christian Hospital, Kwun Tong, Hong Kong

* Corresponding author: ctb021@ha.org.hk

New knowledge added by this study

- For paracetamol overdose in Hong Kong, the failure rate of the 150 -treatment line is $0.45 \%$. Lowering the treatment threshold to 100 -treatment line may lower the failure rate to $0.22 \%$.

- Implementing the 100-treatment line in Hong Kong would incur an annual cost of HK\$189131 (US\$24248), 37 more patients per year needing treatment, and an additional 1.83 anaphylactoid reactions per year. The number needed-to-treat to potentially reduce one significant liver injury is 112 .

Implications for clinical practice or policy

- Clinicians should be aware of the chance of treatment-line failure in patients with acute paracetamol overdose.

- Recommendations for the treatment threshold for acute paracetamol overdose may be evaluated together with the clinical and financial impacts described in this study.

\section{Introduction}

Paracetamol is a common analgesic and antipyretic, and is currently the most commonly overdosed therapeutic agent in Hong Kong, accounting for 8.4\% of all poisoning cases. ${ }^{1}$ After the first human case report of paracetamol-induced liver injury in $1966,{ }^{2}$ paracetamol overdose remains an important cause of acute liver failure with mortalities worldwide. The efficacy of $\mathrm{N}$-acetylcysteine (NAC) in the treatment and prevention of paracetamol-induced liver injury has been established over the last decades. ${ }^{3,4}$ In acute paracetamol overdose, serum paracetamol concentration measured at 4 to 24 hours postingestion (timed serum paracetamol concentration) is plotted on the Rumack-Matthew nomogram. Treatment with NAC should be initiated if the serum paracetamol concentration is plotted on or above the treatment line. ${ }^{5}$ Different treatment lines 


\section{香港的撲熱息痛中毒：150-治療線能否足以檢 測由撲熱息痛中毒引致肝臟受損的病人? \\ 陳俊邦、陳志強、謝萬里}

目的：研究用於指導治療撲熱息痛中毒的 150 -治療線的失敗率, 以及 評估將治療門檻降低對香港醫療系統的影響。

設計：病例系列研究。

安排：香港的公立醫院。

患者：2011年1月 1 日至2013年12月31日期間所有呈報至香港中毒諮 詢中心的急性撲熱息痛中毒個案, 研究病人血液中撲熱息痛濃度和各 自服藥中毒的時間對比得出與不同治療線的關係以及有否出現嚴重肝 藏受損, 同時作出在本地實施不同治療線的成本評估。

結果：共893名病人被納入研究範圍。187（20.9\%）人血液中撲熱息 痛濃度高於 150 -治療線, $112(12.5 \%)$ 人血液中撲熱息痛濃度介乎 150-治療線與100-治療線之間, 而594（66.5\%）人血液中撲熱息痛 濃度則低於 100 -治療線。25（2.8\%）人出現撲熱息痛中毒引致的肝臟 受損。其中兩人血液中撲熱息痛濃度介乎 150 -治療線與 100 -治療線之 間；另有兩人血液中撲熱息痛濃度低於 100 -治療線。150-治療線的失 敗率為 $0.45 \%$ 。將治療基準降至 100 -治療線可將失敗率降至 $0.22 \%$, 而每年須額外治療 37 人。此舉令醫療成本每年增加港幣 189131 元

（即 24248 美元），另每年額外有 1.83 人會出現過敏反應。每額外治 療 112 人即有望減少一例撲熱息痛中毒引致的肝臟受損。

結論：降低治療門檻可將治療線的失敗率降低, 不過執行此改變須考 慮其醫療成本及療程有關之併發症。 exist, however, and there is no worldwide consensus on the safest serum paracetamol concentration at which to initiate NAC treatment.

In the United States, the timed serum paracetamol concentration is plotted against a single treatment line starting at $150 \mathrm{mg} / \mathrm{L}$ at 4 hours post-ingestion (150-treatment line). ${ }^{6}$ Patients with serum paracetamol concentration above this line are treated with NAC. This line was imposed by the United States Food and Drug Administration with a $25 \%$ safety margin based on the work of Rumack in $1975,{ }^{5}$ and was also adopted in Australia and New Zealand.

Previously in the United Kingdom, two different treatment lines were used. Patients were categorised into 'normal risk' or 'high risk' according to their medical and behavioural background. Those patients with possible glutathione depletion, for example with malnutrition or chronic heavy alcoholism, were considered 'high risk' while the remaining patients were considered 'normal risk' Treatment lines starting at $200 \mathrm{mg} / \mathrm{L}$ (200-treatment line) and $100 \mathrm{mg} / \mathrm{L}$ (100-treatment line) at 4 hours post-ingestion were used in patients with 'normal risk' and 'high risk', respectively.

The Medicines and Healthcare products Regulatory Agency of the United Kingdom lowered the threshold of NAC treatment in $2012,{ }^{8}$ following a series of patients with severe liver injury and several mortalities after paracetamol overdose were reported to have a serum paracetamol concentration below the level dictated by the previous treatment protocol. ${ }^{9}$ All patients in the United Kingdom with serum paracetamol concentration over the 100-treatment line are now prescribed NAC treatment.

The Hong Kong Poison Information Centre (HKPIC) currently recommends intravenous NAC treatment in patients with serum paracetamol concentration above the 150-treatment line. One course of NAC treatment typically takes 21 hours of intravenous infusion in hospital under close observation. In this study, we examined a series of non-staggered acute paracetamol overdose cases in Hong Kong to determine how well the current 150-treatment line can cover patients with paracetamol-induced liver injury and the impact on the local health care system if the treatment threshold is changed.

\section{Methods}

We performed a retrospective observational study by reviewing patients with acute paracetamol overdose who presented to 16 emergency departments (EDs) in public hospitals in Hong Kong between 1 January 2011 and 31 December 2013. Data were retrieved from the electronic database of the HKPIC and electronic Patient Record of the Hospital Authority. All patients aged 12 years or above with acute paracetamol overdose were included.

In this study, acute paracetamol overdose was defined as ingestion of paracetamol or paracetamolcontaining medications in a single attempt. As some patients intentionally took a large number of tablets, we allowed a maximum duration of ingestion process for up to 1 hour. When the ingestion process occurred over 1 hour, the overdose was considered to be staggered and such patients were excluded from the study. Patients were also excluded if time of ingestion was undetermined, no serum paracetamol concentration was available within 4 to 24 hours post-ingestion, or patients presented to EDs more than 24 hours post-ingestion.

The following data were collected: clinical profile including age, sex, first serum paracetamol concentration between 4 and 24 hours post-ingestion, treatment given, and the presence of significant liver injury during the episode. Significant liver injury was defined as serum alanine aminotransferase (ALT) level of $\geq 1000 \mathrm{IU} / \mathrm{L}$ in the absence of a known history of deranged liver function.

\section{Results}

There were a total of 1243 patients with acute paracetamol overdose within the study period. Exclusions included 73 patients with staggered 
overdose, 137 patients with undetermined time of line developed significant liver injury. The paracetamol ingestion, 100 patients with no serum failure rate of the 150 -treatment line was $0.45 \%$ paracetamol concentration available within 4 to 24 (4/893). If 100-treatment line is applied instead hours of ingestion, and 40 patients who presented of 150-treatment line, two patients with serum to the EDs of $>24$ hours post-ingestion. Data on 893 paracetamol concentration below the 100-treatment patients who fulfilled the inclusion criteria were line developed significant liver injury. The failure analysed. The clinical data of the studied patients are presented in Table 1.

No deaths occurred in the study population and no patient required liver transplantation. There were 187 (20.9\%) patients with a serum paracetamol concentration above the 150-treatment line, $112(12.5 \%)$ patients had a serum paracetamol concentration between the 100- and 150-treatment lines, and the remaining 594 (66.5\%) patients had serum paracetamol concentration below the 100-treatment line.

Significant liver injury occurred in 25 patients within the study period, giving an overall incidence of $2.8 \%$ following acute paracetamol overdose (Table 2). Four patients with serum paracetamol concentration below the 150-treatment

TABLE I. Clinical data of patients with acute paracetamol overdose $(n=893)$

\begin{tabular}{|c|c|}
\hline Variable & $\begin{array}{l}\text { No. }(\%) \text { of } \\
\text { patients }\end{array}$ \\
\hline \multicolumn{2}{|l|}{ Demographic data } \\
\hline Male & $211(23.6 \%)$ \\
\hline Female & $682(76.4 \%)$ \\
\hline Mean $( \pm \mathrm{SD})$ age (years) & $30.4 \pm 14.5$ \\
\hline \multicolumn{2}{|l|}{ Clinical data } \\
\hline Co-ingestion of other therapeutic agent(s) & $361(40.4 \%)$ \\
\hline Activated charcoal given & $273(30.6 \%)$ \\
\hline Full-course NAC given & $205(23.0 \%)$ \\
\hline$>150-$ Treatment line & $165(18.5 \%)$ \\
\hline 100- to $150-$ Treatment line & $23(2.6 \%)$ \\
\hline$<100-$ Treatment line & $17(1.9 \%)$ \\
\hline Anaphylactoid reaction $†$ & $10(1.1 \%)$ \\
\hline
\end{tabular}

Abbreviations: $\mathrm{NAC}=\mathrm{N}$-acetylcysteine; $\mathrm{SD}=$ standard deviation

* Unless otherwise stated

† Anaphylactoid reaction was defined as the presence of skin rash, hypotension, shortness of breath, or wheezing developing shortly following initiation of intravenous NAC treatment

TABLE 2. Serum paracetamol concentration and the incidence of significant liver injury

\begin{tabular}{lcc}
\hline $\begin{array}{l}\text { Serum paracetamol } \\
\text { concentration }\end{array}$ & $\begin{array}{c}\text { No. of } \\
\text { patients } \\
(\mathbf{n}=\mathbf{8 9 3})\end{array}$ & $\begin{array}{c}\text { No. of patients } \\
\text { with significant } \\
\text { liver injury }(\mathbf{n}=\mathbf{2 5})\end{array}$ \\
\hline <100-Treatment line & 594 & 2 \\
100- to 150-Treatment line & 112 & 2 \\
>150-Treatment line & 187 & 21 \\
\hline
\end{tabular}
$(2 / 893)$.

\section{Discussion}

Paracetamol overdose is a commonly encountered problem in Hong Kong, and is the single most common cause of poisoning. According to the Rumack-Matthew nomogram, a serum paracetamol concentration starting from $200 \mathrm{mg} / \mathrm{L}$ at 4 hours is associated with an increased risk of liver injury and death. ${ }^{10}$ The clinical decision to commence treatment with NAC is dictated by the timed serum paracetamol concentration plotted against the nomogram with a treatment line. If the timed serum paracetamol concentration is above the treatment line, NAC treatment is indicated. Based on different considerations, for example the accuracy of clinical history and individual susceptibility, different treatment lines are applied by different countries or centres to guide initiation of NAC treatment.

Since the United Kingdom lowered the NAC treatment threshold to the 100-treatment line, ${ }^{8}$ there has been discussion in Hong Kong about the benefit of changing local recommendations. Nonetheless, it is unknown whether the reasons for changing the recommendation in the United Kingdom apply to the Hong Kong population. This study serves to provide more information for further discussion and consideration.

We were most interested to identify patients who developed significant liver injury following paracetamol overdose in which the serum paracetamol concentration was lower than the treatment line. In the 3-year study period, four patients with a paracetamol concentration below the 150-treatment line developed significant liver injury. These cases are discussed in detail below and summarised in Table 3.

\section{Case 1}

A 36-year-old woman with known depressive disorder attended the ED 20.5 hours following ingestion of 100 tablets of paracetamol. She had abdominal pain afterwards. On presentation, the paracetamol concentration was $43 \mu \mathrm{mol} / \mathrm{L}$ $(6.5 \mathrm{mg} / \mathrm{L})$. This level falls between the 100- and 150-treatment lines. The level of ALT was $53 \mathrm{IU} / \mathrm{L}$ and international normalised ratio (INR) was 1.03. She was admitted to the medical ward. Although her serum paracetamol concentration plotted below the 150-treatment line, NAC treatment was given soon after admission based on the clinical features 
TABLE 3. Details of patients with significant liver injury below the 150 -treatment line

\begin{tabular}{lccccccc}
\hline Patient No. & $\begin{array}{c}\text { Sex/age } \\
\text { (years) }\end{array}$ & $\begin{array}{c}\text { Serum paracetamol } \\
\text { concentration (mg/L) }\end{array}$ & $\begin{array}{c}\text { Interval from overdose to } \\
\text { blood taking (hours) }\end{array}$ & $\begin{array}{c}\text { ALT increased upon } \\
\text { presentation }\end{array}$ & $\begin{array}{c}\text { Max ALT } \\
\text { (IU/L) }\end{array}$ & $\begin{array}{c}\text { Max INR } \\
\text { Duration of } \\
\text { stay (days) }\end{array}$ \\
\hline 1 & F/36 & 6.5 & 20.5 & No & 3232 & 1.43 & 6 \\
2 & F/31 & 63.3 & 7 & No & 4655 & 1.5 & 4 \\
3 & M/18 & 49.8 & 5 & Yes & 2172 & 1.53 & 6 \\
\hline 4 & M/50 & 4.2 & 20.5 & Yes & 1162 & 1.2 & 6 \\
\hline
\end{tabular}

Abbreviations: $\mathrm{ALT}$ = alanine aminotransferase; INR = international normalised ratio

TABLE 4. Estimation of financial burden for different treatment lines

\begin{tabular}{lccc}
\hline Treatment line & No. of patients & Cost & Average cost per year \\
\hline$>150$-Treatment line & 187 & HK\$947342 (US\$121454) & HK\$315780 (US\$40 485) \\
$>100$-Treatment line & 299 & HK\$1514734 (US\$194197) & HK\$504911 (US\$64733) \\
\hline
\end{tabular}

of hepatitis. Her liver enzyme level started to elevate the next day with clinical jaundice, and on day 2 of admission her ALT level peaked at $3232 \mathrm{IU} / \mathrm{L}$, and INR at 1.43 with bilirubin level of $45 \mu \mathrm{mol} / \mathrm{L}$. She was treated conservatively and liver function gradually improved. She was discharged on day 6 of admission.

\section{Case 2}

A 31-year-old woman attempted suicide by ingesting around 50 tablets of over-the-counter drugs. She was brought to the ED 3 hours afterwards and complained of mild dizziness and nausea. Activated charcoal $50 \mathrm{~g}$ was given and she was admitted to the Intensive Care Unit (ICU). Serum paracetamol concentration taken at 7 hours post-ingestion was $418 \mu \mathrm{mol} / \mathrm{L}$ $(63.3 \mathrm{mg} / \mathrm{L})$, between the 100 - and 150-treatment lines. The patient was treated supportively in the ICU for the first day. At 24-hour post-ingestion her ALT level was $48 \mathrm{IU} / \mathrm{L}$, INR was 1.3, and at 29 hours post-ingestion the ALT level elevated to $73 \mathrm{IU} / \mathrm{L}$, with INR of 1.4. Intravenous NAC treatment was commenced 30 hours post-ingestion. Liver function continued to deteriorate: ALT level peaked at 4655 IU/L and INR peaked at 1.5 on day 3 of admission. The serum bilirubin level was $67 \mu \mathrm{mol} / \mathrm{L}$. She had clinical jaundice and vomiting. On day 4, NAC infusion was stopped. She had full recovery of liver function at 1-month follow-up.

\section{Case 3}

An 18-year-old man ingested around 50 tablets of paracetamol in a suicide attempt. He attended the ED 5 hours later. He was asymptomatic on presentation. Serum paracetamol concentration at 5 hours postingestion was $330 \mu \mathrm{mol} / \mathrm{L}(49.8 \mathrm{mg} / \mathrm{L})$, below the 100-treatment line. At presentation his ALT level was $64 \mathrm{IU} / \mathrm{L}$ and INR was 1.06. Liver function tests repeated at 7 hours post-ingestion showed ALT level was increased to $98 \mathrm{IU} / \mathrm{L}$ and INR was 1.3. Intravenous NAC was started. The liver function deterioration peaked at day 3 of admission with ALT level of $2172 \mathrm{IU} / \mathrm{L}$ and INR of 1.53 and the patient complained of abdominal pain; NAC infusion was continued until day 5 of admission. His liver function improved and he was transferred to the psychiatric ward for management of depression on day 6. He had full recovery of his liver function.

\section{Case 4}

A 50-year-old man had flu-like symptoms and fever for 5 days. He ingested 60 tablets of paracetamol in a suicide attempt related to financial stress and physical discomfort. At 20 hours after ingestion, he attended the ED for recurring fever. On presentation his body temperature was $40.2^{\circ} \mathrm{C}$. Blood tests revealed ALT level of $511 \mathrm{IU} / \mathrm{L}$, INR of 1.1, and serum paracetamol concentration of $28 \mu \mathrm{mol} / \mathrm{L}(4.2 \mathrm{mg} / \mathrm{L})$, below the 100-treatment line at 20.5 hours; NAC treatment was given based on the clinical features of chemical hepatitis. His liver markers peaked the next day with ALT level of 1162 IU/L, INR of 1.2, and with abdominal pain. His fever and respiratory symptoms subsided with a course of intravenous antibiotics. His liver function gradually improved and he was transferred to the psychiatric ward on day 6 after admission.

All four patients were considered 'normal risk' according to the old United Kingdom classification of treatment line options.

Analysis of these four cases revealed that if the NAC treatment threshold had been lowered from the 150-treatment line to 100-treatment line, the treatment line would have covered the first two cases but not the last two. The treatment-line failure 
rate would thus be reduced by half to $0.22 \%$. A lower failure rate of the treatment line implies that people who will develop liver injury following paracetamol overdose are more likely to receive early treatment with NAC. Although not proven in this study, this should prevent a small number of cases of significant morbidity related to severe paracetamol poisoning.

Giving intravenous NAC is not without risk, however. If the 100-treatment line had been applied instead of the 150-treatment line, the number of patients in this study in whom NAC treatment would have been indicated would increase from 187 (20.9\%) to 299 (33.5\%) - an additional 112 courses of NAC over 3 years. In addition, since $4.9 \%$ of the patients given NAC in this study developed an anaphylactoid reaction, there would also have been an additional 5.49 anaphylactoid reactions (1.83 patients/year).

The financial burden of treating additional patients with NAC courses can be estimated by additional cost of hospital stay ${ }^{11}$ and drug cost of NAC, approximately HK\$5066 (US\$650) per standard 21-hour intravenous NAC administration. This is similar to the estimated cost of a standard NAC course in a United Kingdom study. ${ }^{12}$ An additional 112 courses of NAC would cost HK\$567392 (US\$72743) within the study period of 3 years with an average of HK\$189131 (US\$24248) per year. The calculations are shown in Table 4. On rare occasions NAC treatment may be extended over 21 hours and result in a further increase in the actual cost.

The liver injury in case 2 was judged to have been preventable by timely NAC treatment in nomogram perspective. Thus, we would need to administer NAC to an additional 112 patients to achieve potential benefit in one patient. The number needed-to-treat of lowering 150-treatment line to 100-treatment line to potentially prevent one case of paracetamol-induced liver injury is 112 .

Despite these data, the clinical decision to initiate NAC treatment may not depend solely on the timed serum paracetamol concentration. As illustrated in case 1, NAC treatments were occasionally initiated based on the patient's presentation and doctor's clinical judgement. In our study, 23 of 112 patients with serum paracetamol concentration plotted between 100and 150-treatment lines were prescribed NAC for similar reasons. Thus if the 100-treatment line is used instead of the 150-treatment line, the actual number of additional NAC treatment that would have been needed is 89 (ie 112-23 cases).

\section{Limitations}

In the clinical management of paracetamol overdose in Hong Kong, patients may be discharged if their serum paracetamol level is below the treatment line and there are no active clinical symptoms. Although no patient in this study was readmitted for hepatitis, there may have been others who developed chemical hepatitis and who were not brought to our attention. Thus the incidence of liver injury will have been underestimated.

\section{Conclusions}

Neither the 150- nor 100-treatment line can fully cover all patients who develop significant liver injury following paracetamol overdose. The failure rate of the treatment lines and potential financial burden were studied. This serves as the basis for future considerations of treatment in Hong Kong for paracetamol overdose.

\section{References}

1. Chan YC, Tse ML, Lau FL. Hong Kong Poison Information Centre: Annual Report 2012. Hong Kong J Emerg Med 2013;20:371-81.

2. Davidson DG, Eastham WN. Acute liver necrosis following overdose of paracetamol. Br Med J 1966;2:497-9.

3. Prescott LF, Illingworth RN, Critchley JA, Stewart MJ, Adam RD, Proudfoot AT. Intravenous N-acetylcysteine: the treatment of choice for paracetamol poisoning. BMJ 1979;2:1097-100.

4. Smilkstein MJ, Knapp GL, Kulig KW, Rumack BH. Efficacy of oral N-acetylcysteine in the treatment of acetaminophen overdose. Analysis of the national multicenter study (1976 to 1985). N Engl J Med 1988;319:1557-62.

5. Rumack BH. Acetaminophen hepatotoxicity: the first 35 years. J Toxicol Clin Toxicol 2002;40:3-20.

6. Rowden AK, Norvell J, Eldridge DL, Kirk MA. Updates on acetaminophen toxicity. Med Clin North Am 2005;89:114559.

7. Daly FF, Fountain JS, Murray L, Graudins A, Buckley NA; Panel of Australian and New Zealand clinical toxicologists. Guidelines for the management of paracetamol poisoning in Australia and New Zealand-explanation and elaboration. A consensus statement from clinical toxicologists consulting to the Australasian poisons information centres. Med J Aust 2008;188:296-301.

8. Paracetamol overdose: new guidance on use of intravenous acetylcysteine. Commission on Human Medicines, United Kingdom. Available from: https://www.cas. dh.gov.uk/ViewandAcknowledgment/ViewAttachment. aspx?Attachment_id=101488. Accessed 7 Jul 2015.

9. Beer C, Pakravan N, Hudson M, et al. Liver unit admission following paracetamol overdose with concentrations below current UK treatment thresholds. QJM 2007;100:93-6.

10. Rumack BH, Matthew H. Acetaminophen poisoning and toxicity. Pediatrics 1975;55:871-6.

11. Head 140, Expenditure estimates, The 2014-15 Budget, Hong Kong Special Administrative Region, People's Republic of China. Available from: http://www.budget.gov. hk/2014/eng/pdf/head140.pdf. Accessed 19 Nov 2014.

12. McQuade DJ, Dargan PI, Keep J, Wood DM. Paracetamol toxicity: What would be the implications of a change in UK treatment guidelines? Eur J Clin Pharmacol 2012;68:15417. 